\title{
Changes in Respiratory Function Due to Differences in Mask Blocking Grade and Effects on Cardiovascular Function during Aerobic Exercise with Mask
}

\author{
Kwanghyeon Park ${ }^{\mathfrak{\oplus}}$, Sangyeol Lee ${ }^{\mathrm{b}}$ (1)

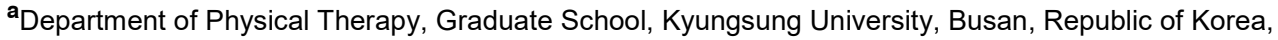 \\ bepartment of Physical Therapy, Kyungsung University, Busan, Republic of Korea
}

Objective: The purpose of this study was to changes in respiratory function due to differences in mask blocking grade, and effects on cardiovascular function during aerobic exercise.

Design: Comparative study using paired t-test and analysis of variance measures.

Methods: Male and female subjects were randomly divided into 4 groups according to mask blocking grade and measured respiratory functions before and after wearing the mask using spirometers, and their cardiovascular capabilities were measured using pulse oxygen meters and blood pressure meters before and after running for 10 minutes wearing mask. Used paired t-test, one-way ANOVA and Bonferroni post-test to compare the differences according to the mask blocking grade.

Results: The experimental results verified that three groups except for the Non-mask group had a significant reduction in all values of FVC, FEV1, MVV, and PEF after wearing a mask compared to those before wearing a mask $(\mathrm{p}<0.05)$. Also a significant difference in cardiovascular functions was also observed after aerobic exercises wearing mask in all groups and there was a significant difference between all four groups $(\mathrm{p}<0.05)$.

Conclusions: Lung patients with poor breathing, elderly and children with poor lung function, and professional groups who need to wear masks and take high-intensity work or aerobic movements are encouraged to take frequent breaks in advance, wear masks and social distancing at moderate and low levels.

Key Words: Aerobic exercise, Cardiopulmonary, Cardiovascularcapability, Mask

서론

최근 미세먼지와 초미세먼지는 사망발생위험을 통계적 으로 유의하게 높이고 있으며 전체연령 집단과 65 세 이상 연령집단에서 미세먼지 $10 \mu \mathrm{g} / \mathrm{m}^{3}$ 증가 시 사망발생 위험 은 $0.44 \%$ 증가하고 초미세먼지 $10 \mu \mathrm{g} / \mathrm{m}^{3}$ 증가 시 전체적 인 사망위험은 $0.95 \%$ 증가하는 것으로 보고하였다[1]. 2013년 12월 환경부는 미세먼지와 초미세먼지가 건강에 미치는 피해를 줄이기 위해 '미세먼지 종합대책'을 시행 하였으며 이에 대한 행동수칙으로 수술용 마스크 착용을 권장하였다[2]. 뿐만 아니라 지난 20년간 2002년 중증급 성호흡기증후군(severe acute respiratory syndrome, SARS),
2009년 신종인플루엔자A(H1N1), 2012년 중동호흡기증 후군(middle east respiratory syndrome, MERS), 그리고 2019년부터 현재까지 코로나바이러스감염증-19(Corona Virus Disease-19, COVID-19)가 계속해서 발병 중이다[3]. 2020 년 1 분기 전 세계적으로 유행하고 있는 COVID-19는 개 인적인 질병을 넘어 국가의 경제적, 사회적 분야 등 각 분 야에 큰 영향을 미치고 있는 것으로 나타났다[4]. 현재는 국가적 차원에서 마스크 착용을 의무화 시킬 만큼 일상에 서의 많은 변화가 나타나고 있다. 마스크를 착용하게 되 면 호기 시 발생되는 이산화탄소가 외부로 원활한 배출이 이뤄지지 않아 마스크 내부의 이산화탄소 농도가 높아지 고, 이에 따라 저산소 환경이 만들어지게 된다[5]. 
마스크를 착용하는 것과 같은 저산소 환경에서는 기초 대사량 증가, 에너지 소비량 증가, 혈중 렙틴 증가, 식욕 감소 등으로 인한 에너지의 불균형을 초래하게 된다. 이 는 체지방량을 감소시키고[6], 같은 부피의 대기 속에 존 재하는 산소의 분자 수가 그만큼 감소하게 됨으로써 같은 양의 공기를 호흡하더라도 혈액 속으로 섭취하는 산소의 양이 줄어들게 되어 동맥혈에 산소 부족 및 저산소 현상 을 초래하게 된다[7]. 만약 저산소 환경에서 운동을 하게 된다면, 적혈구 및 헤모글로빈의 농도, 질량, 수를 증가시 키고 그로 인해 적혈구생성능력이 강화되어[8], 근조직으 로의 헤모글로빈, 마이오글로빈 운반능력을 개선시켜 최 대산소섭취량을 증가시키는 효과를 볼 수도 있다[9].

하지만 일련의 대사과정을 거쳐 퇴행성질환의 시발점 이 되는 위험요소인 산화스트레스를 유발시키고[10], 산 화스트레스 수치를 높여 운동의 효과가 반감될 수 있다는 의문점 또한 같이 제시되고 있으며[11, 최근 장시간 마스 크 착용 시 혹은 마스크를 착용한 채로 운동 시, 혈관 확 장으로 인해 두통을 호소하는 등 장시간 마스크 착용이 인체에 부정적 영향을 미칠 수 있다고 언급되고 있다[12].

특히 한국 마스크의 경우 인체 호흡 기능 및 심혈관계 부담에 대한 시험은 포함되어 있지 않고 더욱이 2020년 12 월부터 '마스크 착용 의무화'가 적용된 시점에서 한국 인을 대상으로 마스크의 차단 등급에 따른 인체 호흡 기 능에 미치는 영향에 대한 연구가 필요하며 더 나아가 마 스크를 착용한 상태에서 유산소 운동이 심혈관계에 미치 는 영향에 대한 세부적인 연구가 필요한 시점이다. 따라 서 본 연구는 마스크 차단 등급에 따른 호흡 기능의 변화 와 유산소 운동 시 심혈관 기능에 미치는 영향에 대해 제 시하고자 한다.

\section{연구 방법}

\section{연구 대상}

본 연구는 부산 전 지역에 거주하고 있는 건강한 20 대 남·여 성인을 대상으로 마스크 종류에 따라 무작위하게 4 그룹으로 나누어 호흡 기능을 마스크 착용 전·후로 측 정하고 마스크를 착용한 상태로 연구 대상자 스스로가 느 끼는 약간 빠른 속도로 트레드밀에서 10 분간 달리게 하였 다. 그룹은 마스크의 종류에 따라 마스크를 착용하지 않 은 그룹(Non-mask), 수술용 마스크 착용 그룹(Dental mask), 보건용 마스크 KF 80 착용 그룹(KF 80 mask), 보건용 마스크 KF 94 착용 그룹(KF 94 mask)으로 총 4 개의 그룹으로 분류하였다. 선정기준은 근골격계통, 심혈 관계통, 고혈압, 천식, 빈혈과 같은 질환이 없고, 마스크를 착용한 상태로 10 분간 트레드밀에서 달리기에 제한이 되 지 않는 자를 선정하였다. 연구 대상자 선정 과정에서 결
과에 영향을 끼칠 수 있는 흡연자는 제외하였다. 또한 연 구 대상자들 간에 개인적인 차이를 배제하기 위해 일반적 인 특성, 호흡 능력, 심혈관 기능, 흡연 유무 등을 고려하 여 연구를 진행하였다. 연구 대상자의 수는 G-power(ver. 3.1.9.2, University of Kiel, Kiel, Germany) 프로그램을 통하여 선행연구의 그룹 간 중재의 변화량에 다른 주요 변수의 값을 계산하여, 효과크기는 0.74 , 유의수준 $\alpha$ 는 0.05 , 검정력(power, $1-\beta)$ 은 0.95 로 설정하였고, 본 연구 의 선정 조건에 부합하지 않은 대상자나 중도 탈락자를 고려하여, $10 \%$ 의 인원수를 추가해 총 40 명의 대상자를 모집하였다.

본 실험을 수행하기 앞서 실험의 목적과 진행 과정을 설명하고 서면동의를 받았으며, 연구 대상자의 기본 정보 를 파악하기 위해 신장, 체중, 질환 유무, 흡연 유무 등의 일반적인 특성을 조사하였다.

\section{측정방법 및 도구}

\section{마스크 착용에 따른 호흡 기능 변화 측정}

마스크 차단 등급에 따른 호흡 기능 변화를 분석하고자 폐활량계(Spiropalm, Cosmed Inc., 이탈리아)를 사용하여 호흡 기능을 측정하였다. 연구 대상자들은 정확한 검사를 위해 의자에 앉은 자세에서 어깨가 이완하고 호흡이 안정 화 될 수 있게 편안하게 호흡을 3 회 실시한 후 측정에 들 어갔다. 마스크 착용 유무에 따른 비교가 필요하여 1차적 으로 마스크를 착용하지 않은 상태에서 호흡 기능을 측정 하였고, 2 차적으로 폐활량계의 마우스피스 앞쪽을 중재에 사용될 마스크와 동일한 재질로 차단한 상태에서 호흡 기 능을 측정하였다. 호흡 기능의 주요지표로는 노력 호기 중에 배출되는 공기의 양을 측정하는 노력성 폐활량(forced vital capacity, FVC)과 노력성 폐활량 측정 과정 중 처음 1 초간에 배출되는 공기의 양을 측정하는 1 초간 노력성 호 기량(forced expiratory volume in one second, FEV1) 그리고 최대 노력성 환기량(maximum voluntary)으로 단 위 시간 내에 자발적 노력으로 할 수 있는 최대의 환기량 을 $\ell / \mathrm{min}$ 으로 표시한 측정값이 있다. 마지막으로 숨을 내 쉬는 호흡의 최대 속도를 의미하는 최대 호기 유속(peak expiratory flow, PEF)을 측정하였다. 측정은 각각 3 회 측정 후 평균값으로 기록하였고, 자세한 측정 방법은 다 음과 같다.

연구 대상자는 치료사의 신호에 맞춰 호흡 기능을 측정 하였고, 측정 간에는 충분한 휴식시간을 부여하였다. 노력 성 폐활량을 측정하기 위해 공기를 최대한 들이 마시고 난 후, 공기를 최대한 느리고 길게 불어 내는 양을 측정하 였고, 1 초간 노력성 호기량은 한쪽 손으로 측정기를 들고 숨을 최대로 깊이 들여 마신 후 가능한 빠르게 끝까지 숨 
을 내쉬는 량 중 처음 1 초 이내의 호기량 $(\mathrm{ml})$ 을 측정하였 다. 최대 노력성 환기량은 1 초간 $1 \sim 2$ 회 정도의 속도로 최 대한 많이 들이마시고 내쉬고를 12 초간 측정하였고, 최대 호기 유속 측정값은 공기를 최대한 들이 마시고 난 후, 공 기를 강하게 내쉴 때의 속도 $(\ell / \mathrm{sec})$ 를 측정하였다[15]. 정 확한 측정을 위해 세 번을 측정하여 평균값을 사용하였다.

\section{유산소 운동 시마스크 착용에 따른 심혈관 기능 변화량 측정}

연구 대상자의 유산소 운동 전·후로 심혈관 기능 변화 를 분석하기 위하여 수축기혈압, 이완기혈압, 산소포화도, 심박수를 측정하였다. 연구 대상자들은 무작위로 배부 받 은 마스크를 착용하고 10 분간 트레드밀에서 달리기를 실 시하였다. 달리기의 강도는 피로감이나 호흡곤란 및 흥통, 어지러움 등의 발생을 예방하기 위해 미국 스포츠 의학회 에서 권장하는 자각피로도 13 과 15 수준으로 설정하여 측정을 진행하였다.

혈압 측정은 전자식 자동 혈압 측정기(녹십자 $\mathrm{CF} 155 \mathrm{~F}$, 로즈맥스, 대한민국)를 사용하였고 방해가 되는 의류는 탈 의하고, 가슴 높이의 책상 위에 팔을 올려둔 상태로 편안 하게 앉은 자세에서 수축기혈압(systolic blood pressure, $\mathrm{SBP}$ )과 이완기혈압(diastolic blood pressure, $\mathrm{DBP})$ 을 측 정하였다. 결과값은 3 회 측정 후 평균값을 기록하였다.

산소포화도와 심박수는 맥박산소계측기(MD300C1, ChoiceMMed, 중국)를 사용하여, 대상자들은 편안하게 앉은 상태에서 왼쪽 검지 손가락에 계측기 센서를 부착하 여 심박수와 혈중 산소포화도를 측정하였다. 모든 측정은 10 분간 트레드밀에서의 유산소 운동 직전과 직후에 실시 하였으며 중재 전 측정 시 충분한 휴식 후 안정 상태에서 측정을 진행하였으며 중재 후 측정 시는 별도의 휴식시간 을 부여하지 않은 상태로 측정을 진행하였다. 측정값의 경우 3 회 측정 하여 평균값을 본 연구에 사용하였으며 맥 박산소계측기는 동맥혈을 채취하여 분석한 결과와 동일한 결과 치를 나타내는 것으로 그 신뢰도가 증명된 바 있다 $[13,14]$.

\section{자료 분석}

본 연구의 자료 분석은 $\operatorname{SPSS}(25.0$ Version, IBM SPSS Inc., USA)통계 프로그램을 사용하여 분석을 실시 하였고, 마스크 차단 등급에 따른 호흡 기능 변화와 유산 소 운동 시 심혈관 기능에 미치는 영향을 전·후로 분석하 기 위하여 대응표본 t검정(Paired t-test)을 실시하였다. 또한 네군의 그룹 간에 비교를 위하여 일원배치 분산분석 (one-way ANOVA)을 실시하였고, 그룹 간의 연관성을 보기 위하여 추가로 Bonferroni 사후검정을 실시하였다. 모든 결과 값은 평균화한 다음 반올림하여 소수점 둘째 자리까지 표기하였고, 통계학적 유의 수준 $(\alpha)$ 은 .05 로 설 정하였다.

\section{연구 결과}

\section{연구 대상지들의 일반적인 특성}

전체 연구 대상자 40 명의 평균연령은 $25.85 \pm 1.67$ 세로 나타났으며 평균 신장 $174.13 \pm 9.23 \mathrm{~cm}$, 평균 체중 $68.53 \pm$ $14.00 \mathrm{~kg}$ 이다. 전체 남녀의 성비는 남성이 $72.50 \%$, 여성 이 $27.50 \%$ 의 비중을 차지하였다.

\section{마스크 착용 전 · 후 그룹 별 호흡 기능}

수술용 마스크 착용 그룹, 보건용 마스크 $\mathrm{KF} 80$ 착용 그룹, 보건용 마스크 KF 94 착용 그룹 모두에서 마스크 착용 전 보다 착용 후에 호흡 기능에서 통계적으로 유의 미한 차이가 있었다 $(\mathrm{p}<0.05)$.

\section{마스크 착용 전 · 후 그룹 간 호흡 기능 변화량 비교}

마스크의 종류에 따른 네 그룹 간 노력성 폐활량, 1 초 간 노력성 호기량, 최대 노력성 환기량, 최대 호기 유속과 같은 호흡 기능 변화량 비교에서 통계적으로 유의미한 차 이가 있었다 $(\mathrm{p}<0.05)($ Table 1$)$.

Table 1. Comparison of breathing ability blocking effects before and after wearing mask based on mask blocking ratings among different groups

$(\mathrm{N}=40)$

\begin{tabular}{lllllll}
\hline Variables & Nonmask $(\mathbf{N}=10)$ & Dental mask $(\mathbf{N}=10)$ & KF 80 mask $(\mathbf{N}=10)$ & KF 94 mask $(\mathbf{N}=10)$ & F & p \\
\hline FVC $(\ell)$ & $0^{\mathrm{a}}$ & $-0.37 \pm 0.27^{\dagger \mathrm{a}}$ & $-1.6 \pm 0.76^{\mathrm{b}}$ & $-1.33 \pm 0.67^{\mathrm{b}}$ & 20.977 & $0.000^{*}$ \\
$\mathrm{FVE} 1(\ell / \mathrm{sec})$ & $0^{\mathrm{a}}$ & $-0.71 \pm 0.56^{\mathrm{a}, \mathrm{b}}$ & $-1.47 \pm 0.69^{\mathrm{b}, \mathrm{c}}$ & $-1.73 \pm 0.96^{\mathrm{c}}$ & 13.800 & $0.000^{*}$ \\
$\mathrm{MVV}(\ell / \mathrm{min})$ & $0^{\mathrm{a}}$ & $-70.44 \pm 29.30^{\mathrm{b}}$ & $-96.28 \pm 28.52^{\mathrm{b}, \mathrm{c}}$ & $-102.99 \pm 25.91^{\mathrm{c}}$ & 37.858 & $0.000^{*}$ \\
$\operatorname{PEF}(\ell / \mathrm{sec})$ & $0^{\mathrm{a}}$ & $-3.80 \pm 1.17^{\mathrm{b}}$ & $-5.00 \pm 1.88^{\mathrm{b}, \mathrm{c}}$ & $-5.97 \pm 2.08^{\mathrm{c}}$ & 29.650 & $0.000^{*}$ \\
\hline
\end{tabular}

${ }^{\dagger}$ Values are presented as mean \pm standard deviation or number, ${ }^{*} \mathrm{p}<0.05$

The values with different superscripts ${ }^{(a, b)}$ in the same column are significantly $\operatorname{different}(\mathrm{p}<0.05)$ 
노력성 폐활량은 마스크를 착용하지 않은 그룹과 수술 용 마스크 착용 그룹 간 통계적으로 유의미한 차이가 없 었고, 보건용 마스크 $\mathrm{KF} 80$ 착용 그룹과 보건용 마스크 $\mathrm{KF} 94$ 착용 그룹 간에도 유의미한 차이가 없었다 $(\mathrm{p}>$ $0.05)$. 하지만 보건용 마스크 $\mathrm{KF} 80$ 착용 그룹과 보건용 마스크 KF 94 착용 그룹이 마스크를 착용하지 않은 그룹 과 수술용 마스크 착용 그룹보다 더욱 많은 감소를 보였 다 $(\mathrm{p}<0.05)($ Table 1$)$.

1 초간 노력성 호기량은 마스크를 착용하지 않은 그룹 과 수술용 마스크 착용 그룹 간에 통계적으로 유의미한 차이는 없었고 $(\mathrm{p}>0.05)$, 마스크를 착용하지 않은 그룹보 다 보건용 마스크 $\mathrm{KF} 80$ 착용 그룹과 보건용 마스크 $\mathrm{KF}$ 94 착용 그룹에서 더 많은 1 초간 노력성 호기량의 감소가 나타났다 $(\mathrm{p}<0.05)$. 비교적 낮은 차단 등급에 속하는 수술 용 마스크 착용 그룹과 비교적 높은 차단 등급에 속하는 보건용 마스크 KF 80 착용 그룹 사이에서는 통계적으로 유의미한 차이가 없었고, 높은 차단 등급에 속하는 보건 용 마스크 KF 80 착용 그룹과 보건용 마스크 KF 94 착 용 그룹 간에서도 통계적으로 유의미한 차이는 없었다 $(\mathrm{p}>0.05)$. 마스크를 착용하지 않은 그룹과 수술용 마스크 착용 그룹 사이에서 통계적으로 유의미한 차이는 없었지 만 $(\mathrm{p}>0.05)$, 마스크 차단 등급이 높아질수록 1 초간 노력 성 호기량의 저하되는 폭이 증가하였고 보건용 마스크 KF 94 착용 그룹은 마스크를 착용하지 않은 그룹과 수술 용 마스크 착용 그룹보다 더욱 많은 1 초간 노력성 호기량 의 감소가 나타났다 $(\mathrm{p}<0.05)($ Table 1$)$.

최대 노력성 환기량과 최대 호기 유속은 수술용 마스크 착용 그룹과 보건용 마스크 KF 80 착용 그룹 간에 통계 적으로 유의미한 차이는 없었고 보건용 마스크 $\mathrm{KF} 80$ 착 용 그룹과 보건용 마스크 KF 94 착용 그룹 간에도 통계 적으로 유의미한 차이는 없었다 $(\mathrm{p}>0.05)$. 하지만 마스크 를 착용하지 않은 그룹에서 수술용 마스크 착용 그룹, 보 건용 마스크 $\mathrm{KF} 80$ 착용 그룹 그리고 보건용 마스크 $\mathrm{KF}$ 94 착용 그룹으로 마스크의 차단 등급이 높아질수록 더욱 많은 감소가 나타났다 $(\mathrm{p}<0.05)($ Table 1$)$.

\section{유산소 운동 전 · 후 그룹 별 심혈관 기능 비교}

마스크를 착용하지 않은 그룹, 수술용 마스크 착용 그 룹, 보건용 마스크 $\mathrm{KF} 80$ 착용 그룹, 보건용 마스크 $\mathrm{KF}$ 94 착용 그룹 모든 그룹에서 유산소 운동 전·후로수축기 혈압, 이완기혈압, 심박수, 산소포화도와 같은 항목 모두 에서 통계적으로 유의미한 차이가 있었다 $(\mathrm{p}<0.05)$.

\section{유산소 운동 전 · 후 그룹 간 심혈관 기능 변화량 비교}

마스크를 착용한 상태에서 실시된 유산소 운동 전·후 심혈관 기능의 변화량을 비교한 결과, 마스크를 착용하지 않은 그룹, 수술용 마스크 착용 그룹, 보건용 마스크 $\mathrm{KF}$ 80 착용 그룹, 보건용 마스크 KF 94 착용그룹의 수축기 혈압, 이완기혈압, 심박수, 산소포화도 변화량에서 모두 그룹 간 통계적으로 유의미한 차이가 있었다 $(\mathrm{p}<0.05)$ (Table 2).

수축기혈압은 마스크를 착용하지 않은 그룹이 수술용 마스크 착용 그룹, 보건용 마스크 KF 80 착용 그룹과는 통계적으로 유의미한 차이가 없었고, 수술용 마스크 착용 그룹은 마스크를 착용하지 않은 그룹과 보건용 마스크 $\mathrm{KF} 80$ 착용 그룹과 통계적으로 유의미한 차이가 없었다 $(\mathrm{p}>0.05)$. 하지만 두 그룹 모두 보건용 마스크 KF 94 착 용 그룹과 통계적으로 유의미한 차이가 있었다 $(\mathrm{p}<0.05)$. 보건용 마스크 KF 94 착용 그룹은 보건용 마스크 KF 80 착용 그룹을 제외한 나머지 그룹들 모두와 통계적으로 유 의미한 차이가 있었다 $(\mathrm{p}<0.05)($ Table 2$)$.

이완기혈압은 수술용 마스크 착용 그룹은 어느 그룹과 도 통계적으로 유의미한 차이가 없었고 $(\mathrm{p}>0.05)$, 보건용 마스크 KF 80 착용 그룹과 보건용 마스크 $\mathrm{KF} 94$ 착용 그룹 간의 평균차이에서도 통계적으로 유의미한 차이가 없었다 $(\mathrm{p}>0.05)$. 하지만 마스크를 착용하지 않은 그룹은 보건용 마스크 KF 80 착용 그룹, 보건용 마스크 KF 94 착용 그룹과 통계적으로 유의미한 차이가 있었고 높은 차 단 등급의 마스크인 보건용 마스크 KF 94 착용 그룹에서 더 많은 혈압의 증가가 있었다 $(\mathrm{p}<0.05)($ Table 2).

Table 2. Post-hoc comparison of cardiovascular and oxygen saturation blocking effects before and after aerobic exercise for 10 minutes wearing a mask based on mask blocking grade among different groups

$(\mathrm{n}=40)$

\begin{tabular}{lllllll}
\hline Variables & Non mask $(\mathbf{N}=10)$ & Dentalmask $(\mathbf{N}=10)$ & KF 80 mask $(\mathbf{N}=10)$ & KF 94 mask $(\mathbf{N}=10)$ & F & p \\
\hline $\mathrm{SBP}(\mathrm{mmHg})$ & $5.00 \pm 2.67^{\dagger \mathrm{a}}$ & $6.90 \pm 5.38^{\mathrm{a}}$ & $9.40 \pm 2.01^{\mathrm{ab}}$ & $11.80 \pm 4.02^{\mathrm{b}}$ & 6.228 & $0.002^{*}$ \\
$\mathrm{DBP}(\mathrm{mmHg})$ & $2.50 \pm 3.06^{\mathrm{a}}$ & $4.60 \pm 3.37^{\mathrm{ab}}$ & $7.70 \pm 2.11^{\mathrm{b}}$ & $8.00 \pm 4.99^{\mathrm{b}}$ & 5.518 & $0.003^{*}$ \\
$\mathrm{HR}(\mathrm{bpm})$ & $4.20 \pm 2.44^{\mathrm{a}}$ & $5.30 \pm 2.41^{\mathrm{a}}$ & $8.00 \pm 4.27^{\mathrm{ab}}$ & $9.60 \pm 3.81^{\mathrm{b}}$ & 5.485 & $0.003^{*}$ \\
$\mathrm{SpO}_{2}(\%)$ & $-0.40 \pm 0.52^{\mathrm{a}}$ & $-0.90 \pm 0.57^{\mathrm{a}}$ & $-1.60 \pm 0.52^{\mathrm{b}}$ & $-2.20 \pm 0.88^{\mathrm{b}}$ & 19.832 & $0.000^{*}$ \\
\hline
\end{tabular}

${ }^{\dagger}$ Values are presented as mean \pm standard deviation or number, ${ }^{*} \mathrm{p}<0.05$

The values with different superscripts ${ }^{(a, b)}$ in the same column are significantly different $(\mathrm{p}<0.05)$ 
심박수는 보건용 마스크 $\mathrm{KF} 80$ 착용 그룹은 어떠한 그룹과도 통계적으로 유의미한 차이가 없었고 $(\mathrm{p}>0.05)$, 마스크를 착용하지 않은 그룹과 수술용 마스크 착용 그룹 은 보건용 마스크 $\mathrm{KF} 94$ 착용 그룹과 통계적으로 유의미 한 차이가 있었다 $(\mathrm{p}<0.05)($ Table 2$)$.

산소포화도는 마스크를 착용하지 않은 그룹과 수술용 마스크 착용 그룹 사이에는 통계적으로 유의미한 차이가 없었지만 $(\mathrm{p}>0.05)$, 보건용 마스크 $\mathrm{KF} 80$ 착용 그룹 그 리고 보건용 마스크 $\mathrm{KF} 94$ 착용 그룹으로 차단 등급이 높아질수록 더 많은 산소포화도의 감소가 있었다 $(\mathrm{p}<0.05)$. 수술용 마스크 착용 그룹 또한 보건용 마스크 $\mathrm{KF} 80$ 착 용 그룹, 보건용 마스크 KF 94 착용 그룹과 통계적으로 유의미한 차이가 있었고 $(\mathrm{p}<0.05)$, 보건용 마스크 KF 80 착용 그룹과 보건용 마스크 KF 94 착용 그룹 사이에서는 통계적으로 유의미한 차이가 없었다 $(\mathrm{p}>0.05)($ Table 2).

\section{고찰}

마스크를 착용하게 되면 마스크 내부의 호흡 유동에 변 화가 생기게 되어 저산소 환경이 만들어져 다양한 신체적 불균형을 초래하게 된다[5,6]. 하지만 저산소 환경이 만들 어짐에 따라 마스크 착용 전·후로 나타날 수 있는 실질 적인 호흡능력의 변화나 마스크를 착용한 상태에서 유산 소적인 움직임을 취하는데 있어 어떠한 위험성과 신체에 어떤 영향을 미치는지 인지하지 못하는 실정이며, 실제 마스크의 차단 등급을 일정한 기준에 따라 분류하는 식품 의약품안전처의 검사에서도 인체에 미치는 영향에 대한 검사가 빠져있다. 이에 마스크 차단 등급에 따른 호흡 기 능 변화와 유산소 운동 시 심혈관 기능에 미치는 영향에 대해 정량적 자료가 필요하며, 이를 알아보기 위하여 본 연구를 진행하였다.

본 연구는 두 가지 단계적 실험으로 구성되었으며 1단 계 실험은 마스크의 차단 정도가 대상자의 호흡 기능에 미치는 영향을 밝히고자 하였고, 2 단계 실험은 마스크를 착용하고 유산소 운동 후 신체에 나타나는 심혈관 기능의 변화를 알아보고자 하였다. 1 단계 실험의 결과로 종류와 상관없이 마스크의 착용은 호흡 기능의 즉각적인 저하를 일으키고, 차단 등급이 높아질수록 더 많은 호흡 기능의 저하가 나타났다.

호흡 기능을 종합적으로 해석해보면 Sawaya 등[16]의 연구에서 골격근량은 폐활량과 호흡 근력에 상관관계가 있다고 하였다. 이는 남성과 여성의 골격근량의 차이로 인해 폐활량과 호흡 근력의 차이가 나타날 수 있다고 하 였다. 따라서 골격근량이 남성보다 상대적으로 떨어지는 여성의 경우 수술용 마스크보다 높은 차단 등급의 마스크 를 착용할 경우 폐활량에 있어 호흡 시 불편감을 느낄 수
있기 때문에 높은 차단 등급의 마스크를 착용하였을 경우, 휴식시간을 자주 가지기를 권장한다. 또한 동적인 행위와 정적인 행위에 구분 짓기 이전에 종류에 관계없이 마스크 를 착용하게 되면 통계적으로 호흡능력에 유의미한 차이 가 생기기 때문에 높은 차단 등급의 마스크보다 상대적으 로 수치가 적게 감소되는 낮은 차단 등급의 마스크를 착 용을 권장한다. 하지만 바이러스나 고강도의 업무 등으로 인해 높은 차단 등급의 마스크를 착용해야 할 경우 휴식 시간을 자주 갖거나 업무의 강도를 조절하는 것이 필요하 다고 생각한다. 앞서 언급된 호흡기능은 기계적인 힘을 만들기 위해 발생되는 근육의 대사 작용, 근육의 모세혈 관과 미토콘드리아 사이의 가스 이동, 혈액의 공급, 산소 와 이산화탄소 운반능력, 폐혈관 기능 등과 상호적으로 연결되어 있다고 한다[17]. 따라서 마스크 착용으로 나타 나는 즉각적인 호흡기능의 감소는 신체 전반적인 부분에 다양한 문제를 야기시킬 수 있다고 생각한다.

2단계 실험의 결과로 심혈관 기능 또한 모든 그룹에서 유산소 운동 후에 심혈관 기능의 저하가 나타났고, 마스 크를 착용하지 않거나 수술용 마스크를 착용한 그룹에 비 해 KF 94 마스크를 착용한 그룹에서 더 많은 심혈관 기 능의 저하가 나타났다. 1,2 단계의 실험에서 마스크를 착 용하지 않은 그룹과 수술용 마스크를 착용한 그룹 간에는 큰 연관성을 찾기 힘들었지만 마스크를 착용하지 않은 그 룹과 수술용 마스크를 착용한 그룹들과 상대적으로 높은 차단 등급인 $\mathrm{KF}$ 마스크 그룹들과 비교 시 많은 차이가 나타났다.

혈압과 관련된 문제 중 특히 고혈압은 종종 심혈관 질 환 및 신장 질환으로 이어지며 전 세계적으로 중요한 문 제이다[18]. 기준에 따른 차이가 있지만 일반적으로 수축 기혈압이 $140 \mathrm{mmHg}$ 를 넘거나, 이완기혈압이 $90 \mathrm{mmHg}$ 를 넘으면 고혈압이라고 진단한다[19]. 현재 우리나라에서 고혈압은 유병율이 높음에도 환자의 $75 \%$ 가 자신의 혈압 을 정확히 알지 못하고 치료를 받는 사람도 $10 \%$ 정도만 이 자신의 혈압을 정확히 인식할 뿐 아니라 적절히 관리 를 하고 있는 사람은 $5 \%$ 에 불과하다[20,21]. 이러한 고혈 압의 관리가 제대로 되지 않아 고혈압 및 관련 질환으로 인한 장애와 사망 등의 문제가 많이 발생하고 있다. 더구 나 고혈압은 초기 증상을 본인이 느끼지 못하는 경우가 대부분이며 본인이 혈압이 높다는 사실을 모르는 경우가 매우 많다[22]. Kim 등 [23]의 연구에서 혈압은 심혈관계 질환에 의한 사망률과 이환율이 연관성이 있다고 언급하 였다. 이는 본 연구의 결과인 KF 94 마스크를 착용하게 되면 수축기혈압이 증가한다는 결과를 토대로 고혈압 환 자나 평소 혈압이 높은 사람, 그리고 마스크를 착용하고 운동을 할 수 밖에 없는 현대인들과 운동선수들에게 있어 높은 차단 등급의 마스크를 착용해야한다면 잦은 휴식과 
운동 강도의 조절과 같은 주의가 필요하다고 생각한다. 현재 이전의 생각과는 달리 운동 중 마스크의 착용이 바 이러스의 물방울 전달로부터 추가 보호를 제공한다는 주 장의 근거는 없어 실제 운동 중 마스크 착용보다 사회적 거리를 두는 것이 더 좋으며 운동 중 마스크를 착용하는 것보다 최적의 활용이라 권장하고 있다[12]

자율신경계의 활동, 심폐 건강을 결정하는 심박수의 증 가는 심혈관 질환의 위험성을 증가시킬 수 있다고 보고되 고 있다[24,25,26]. 심박수의 증가는 심장주기의 이완기 기간을 단축시키고 심장 부하를 증가시키며 동맥경화증과 같은 심혈관 질환의 촉진적인 위험 요소가 된다[27]. 따라 서 유산소 운동과 같은 동적인 움직임을 취할 경우 혹은 심혈관 질환이 있는 환자가 $\mathrm{KF}$ 94와 같이 높은 차단 등 급의 마스크를 착용했을 경우 휴식시간을 많이 가지는 것 을 권장하며 이는 운동 혹은 신체적으로 산소를 더 필요 로 하는 고강도 작업 시 마스크를 착용해야 할 경우 호흡 저항이 적고 여과효율 수준이 적절한 마스크를 착용하는 것을 권장한다는 정재연[28]의 연구결과와 동일한 결과가 나왔다.

인간의 혈중 산소포화도는 $95 \%$ 이상으로 유지되고 산 소는 인체에서 대사 작용이 가장 활발한 기관인 뇌 활동 에 중요한 물질로서, 중추신경계는 산소 부족에 가장 민 감한 조직이며, 동맥혈 산소 분압의 저하는 주의력, 기억 력, 의사결정 능력 등의 뇌기능에 변화를 초래한다고 한 다[29,30]. 산소 농도가 저하되면 현저한 피로를 호소하고 반응속도,기억, 공간, 언어, 덧셈과 같은 인지수행 능력을 저하 시킨다고 보고되었다[31,32,33,34,35,36]. 따라서 장 시간 운전 혹은 집중을 요하는 경우 수술용 마스크의 착 용을 권장하나 감염병의 위험으로 인해 $\mathrm{KF}$ 마스크를 착 용해야 할 경우 KF 94 보다는 낮은 차단 등급인 KF 80 마스크의 착용을 권장한다. 그렇지 못 할 경우 충분한 휴 식시간의 부여가 필요하다고 생각한다. 세계보건기구와 미국 질병통제예방센터에서는 운동 중 마스크 착용을 권 장하지 않고 있으며, 고강도 신체 활동 중에 마스크를 착 용하는 것이 어려울 수 있다고 언급하고 있다[37]. 특히 마스크를 착용하고 운동을 진행할 경우 신체 부정적인 영 항을 피하기 위하여 개인은 먼저 자신의 운동 능력을 파 악하고 운동 강도를 조절하여야 한다. 마스크를 착용하고 낮은 강도에서 중간 강도의 운동은 신체에 유익하고 마스 크를 착용한 상태에서 발생 할 수 있는 부작용을 줄이는 데 도움을 줄 수 있지만 운동 중 어지러움, 불균형, 과도 한 피로를 경험할 때, 그리고 숨이 차는 경우 증상이 가라 앉을 때까지 운동을 멈추고 휴식을 취하는 것을 권장한다 [38].

본 연구의 제한점으로 산소포화도를측정 할 당시 유산 소 운동을 마친 직후에 측정을 하여 시간이 경과함에 따
른 회복기의 사후 측정을 하지 못하여 그룹 간에 얼마나 빠르게 회복되는지 확인하지 못하였고, 그룹 간 최대한 유사한 디자인의 마스크를 착용자의 안면에 밀착시켜 착 용하고 실제 일상에서 마스크를 착용하는 형태를 고려하 여 연구를 진행하였지만 각 마스크 간의 완전히 동일한 디자인의 마스크를 구하지 못한 점과 착용자의 얼굴 크기 차이로 인한 마스크 내부 공간을 통제하지 못한 점을 제 한점으로 들 수 있다.

세계보건기구[39]와 정재연[28]의 연구에서어린이들의 경우 성인보다 신체적으로 더 활동적이고, 발육의 다양한 활동을 위해 더 많은 산소를 필요로 하기 때문에 어린이 들에게 마스크 내부 공간이 더 큰 마스크를 착용하여야 한다고 언급하고 있다. 따라서 향후 마스크 착용이 신체 에 미치는 영향을 연령기에 따른 세분화와 마스크를 착용 하고 유산소 운동 시 운동의 강도를 체계화하여 신체에 미칠 수 있는 영향에 대한 연구가 필요하다 생각하며 나 아가 바이러스나 호흡계통 질환의 예방 효과는 유지되면 서 인체에 부정적 영향을 미치지 않는 기능성 마스크의 개발 또한 필요하다고 생각한다.

\section{결론}

마스크의 착용은 즉각적인 호흡 기능의 저하를 일으키 고, 마스크를 착용한 상태로 유산소 운동 시 심혈관 기능 에 부정적인 영향을 미칠 수 있다.이에 호흡 기능이 떨어 지는 폐질환자, 저하된 호흡 기능을 가진 고령자 및 아이 들, 그리고 일반인 및 운동 선수들의 운동시본인의 심폐 능력을 미리 파악하고 중등도 및 낮은 강도에서 마스크의 착용과 사회적 거리두기를 병행한 활동을 진행하길 권장 하며 마스크를 착용하고 고강도의 신체 노동을 하는 직업 군들의 경우 충분하고 주기적인 휴식시간 및 노동 강도의 조절을 권장하는 바이다.

\section{참고문헌}

1. Gong SY, Bae HJ, Yoon DO, Hong SP, Park HY. A Study on the Health Impact and Management Policy of pm2. 5 in Korea. Korea Environment Institute 2012;190.

2. Ministry of Environment of Korea. "Joint announcement of comprehensive fine dust measure". 2013.

3. World Health Organization. Coronavirus disease (COVID-19). 2020.

4. Ju W, Hong JP, Oh JB, Sin YL, Chun YC. The Impact of The Novel Coronavirus Infection on The 
Korean Economy-Economic Growth Rate in 2020 $0.1 \sim 0.2 \%$ p Downward Pressure. Hyundai Research Institute 2020;868:1-16.

5. Yu JW, Kim YJ, Heo NG. A Numerical Analysis on Respiratory Flow Characteristics in Wearing a Mask. The Korean Society of Mechanical Engineers 2018;426-427.

6. Hamad N, Travis SP. Weight loss at high altitude: pathophysiology and practical implications. Eur $\mathrm{J}$ Gastroenterol Hepatol 2006;18(1):5-10.

7. Botek M, Krejčí J, De Smet S, Gába A, McKune AJ. Heart rate variability and arterial oxygen saturation response during extreme normobaric hypoxia. Autonomic Neuroscience 2015;190:40-45.

8. Sinex JA, Chapman RF. Hypoxic training methods for improving endurance exercise performance. Journal of Sport and Health Science 2015;4(4):325-332.

9. Hamlin MJ, Marshall HC, Hellemans J, Ainslie PN, Anglem N. Effect of intermittent hypoxic training on $20 \mathrm{~km}$ time trial and $30 \mathrm{~s}$ anaerobic performance. Scand J Med Sci Sports 2010;20(4):651-661.

10. Simioni C, Zauli G, Martelli AM, Vitale M, Sacchetti G, Gonelli A, et al. Oxidative stress: role of physical exercise and antioxidant nutraceuticals in adulthood and aging. Oncotarget 2018;9(24):17181.

11. Debevec T, Millet GP, Pialoux V. Hypoxia-induced oxidative stress modulation with physical activity. Frontiers in physiology 2017;8:84.

12. Chandrasekaran B, Fernandes S. "Exercise with facemask; Are we handling a devil's sword?"-A physiological hypothesis. Med Hypotheses 2020;144: 110002.

13. Martin D, Powers S, Cicale M, Collop N, Huang D, Criswell D. Validity of pulse oximetry during exercise in elite endurance athletes. J Appl Physiol 1992;72(2):455-458.

14. Benoit H, Costes F, Feasson L, Lacour JR, Roche F, Denis C, et al. Accuracy of pulse oximetry during intense exercise under severe hypoxic conditions. Eur J Appl PhysiolOccupPhysiol 1997;76(3):260-263.

15. Seo K, Kim H, Yim S. The effects of pulmonary function in the stroke patients after thoracic expension exercise. Journal of the Korean Society of Physical Medicine 2012;7(2):157-164.

16. Sawaya Y, Ishizaka M, Kubo A, Sadakiyo K, Yakabi A, Sato T, et al. Correlation between skel- etal muscle mass index and parameters of respiratory function and muscle strength in young healthy adults according to gender. Journal of physical therapy science 2018;30(12):1424-1427.

17. Roman MA, Rossiter HB, Casaburi R. Exercise, ageing and the lung. European Respiratory Journal 2016;48(5):1471-1486.

18. Kearney PM, Whelton M, Reynolds K, Muntner P, Whelton PK, He J. Global burden of hypertension: analysis of worldwide data. The lancet 2005;365(9455): 217-223.

19. Carretero OA, Oparil S. Essential hypertension: part I: definition and etiology. Circulation 2000;101(3):329-335.

20. Development of decision support system for the management of hypertension using data mining technology. Proceedings of the conference the Korean Society of Intelligent information System; 2000.

21. Kim H, Jee S, Lee K, Kim C, Nam C, Suh I. Twelve-year incidence of hypertension and its risk factors in a lean population: the Kangwha study. Journal of Preventive Medicine and Public Health 1999;32(4):435-442.

22. Jung HS, Jhang WG. An intervention study for hypertension in small scale enterprises based on transtheoretical and ecological model. Korean Journal of Occupational Health Nursing 2006;15(2):153-164.

23. Kim YM, Choi HR, Park DY, Lim JB, Won CW, $\mathrm{Kim} \mathrm{BS}$, et al. The comparision of the quality of life between the well controlled hypertension group and the uncontrolled hypertension group. Journal of the Korean Academy of Family Medicine 2001;22(4): 565-574.

24. Fox K, Borer JS, Camm AJ, Danchin N, Ferrari R, Lopez Sendon JL, et al. Resting heart rate in cardiovascular disease. J Am Coll Cardiol 2007;50(9): 823-830.

25. Oda E, Aizawa Y. Resting heart rate predicts metabolic syndrome in apparently healthy non-obese Japanese men. Acta Diabetol 2014;51(1):85-90.

26. Verrier RL, Tan A. Heart rate, autonomic markers, and cardiac mortality. Heart rhythm 2009;6(11):S68-S75.

27. Kang S, Kim E, Ko K. Effects of aerobic exercise on the resting heart rate, physical fitness, and arterial stiffness of female patients with metabolic syndrome. Journal of physical therapy science 2016; 28(6):1764-1768. 
28. Jung JY. Performance Evaluation of Face Masks : Inhalation resistance, Fit factor, Total inward Leakage and respiratory burden. Seoul: Seoul National University; 2021

29. Fujiwara T, Maeda M. Effects of oxygen and refresh space for the elderly. Journal of Human Life Engineering 2001;2(3):8-11.

30. Horwitz B, McIntosh AR, Haxby JV, Grady CL. Network analysis of brain cognitive function using metabolic and blood flow data. Behav Brain Res 1995;66(1-2):187-193.

31. Chung S, Kwon J, Lee H, Tack G, Lee B, Yi J, et al. Effects of high concentration oxygen administration on n-back task performance and physiological signals. PhysiolMeas 2007;28(4):389.

32. Chung S, Lee B, Tack G, Yi J, Lee H, Kwon J, et al. Physiological mechanism underlying the improvement in visuospatial performance due to $30 \%$ oxygen inhalation. Appl Ergon 2008;39(2):166-170.

33. Chung S, Lim D. Changes in memory performance, heart rate, and blood oxygen saturation due to $30 \%$ oxygen administration. Int $\mathrm{J}$ Neurosci 2008;118(4): 593-606

34. Moss MC, Scholey AB, Wesnes K. Oxygen administration selectively enhances cognitive performance in healthy young adults: a placebo-controlled double-blind crossover study. Psychopharmacology (Berl) 1998;138(1):27-33.

35. Scholey AB, Moss MC, Neave N, Wesnes K. Cognitive performance, hyperoxia, and heart rate following oxygen administration in healthy young adults. PhysiolBehav 1999;67(5):783-789.

36. Winder R, Borrill J. Fuels for memory: the role of oxygen and glucose in memory enhancement. Psychopharmacology (Berl) 1998;136(4):349-356.

37. Centers for Disease Control and Prevention(CDC). (2020). COVID-19: Considerations for Wearing Masks.

38. Sakaguchi H, Wada K, Kajioka J, Watanabe M, Nakano R, Hirose T, et al. Maintenance of influenza virus infectivity on the surfaces of personal protective equipment and clothing used in healthcare settings. Environmental health and preventive medicine 2010;15(6):344-349.

39. World Health Organization. (2008). Children are not little adults. 